\title{
STUDIES OF SOME BIOLOGICAL AND PHYSICOCHEMICAL PROPERTIES OF HERPES SIMPLEX VIRUS TYPE 2 GROWTH FACTOR (HSGF-2)
}

\author{
Z. ŽIVICOVÁ', J. GAŠPERÍK', J. LEŠKO’, F. GOLAIS'
}

'Comenius University, Department of Microbiology and Virology, Bratislava, 2Institute of Molecular Biology, Slovak Academy of Sciences, Bratislava, 'Institute of Virology, Slovak Academy of Sciences, Bratislava, Slovak Republic

Received June 12, 1998

Accepted August 19, 1998

\begin{abstract}
Živicová, Z., J. Gašperik, J. Leško, F. Golais: Studies of Some Biological and Physicochemical Properties of Herpes simplex Virus Type 2 Growth Factor (HSGF-2). Acta vet. Brno 1998, 67: 159-165.

Herpes simplex virus type 2 (HSV-2) growth factor (HSGF-2) consists of three components. HSGF- $2_{A}$ and HSGF- $2_{C}$ components have an ability to transform cultured cells in vitro, whereas the HSGF- $2_{\mathrm{B}}$ component changes the transformed phenotype towards the normal one. For production of functional HSGF-2, glucose and $\mathrm{Ca}^{2}+$ ions are required. The replacement of glucose by some other monosaccharides, or the presence of three cytostatics in the medium of HSGF-2 producing MK-2 cell influenced both the biological activity and the component characteristics of HSGF-2. Heating. low pH, or UV light elevated the transforming. but not the transformed phenotype repressing activity of HSGF-2. Heparin destroyed the suppressing effect on transformed phenotype. without any influence on transforming activity of HSGF-2. All presented results are compared with similar or different results obtained with pseudorabies virus growth factor (PRGF).
\end{abstract}

Herpes simplex virus type 2 growth factor, monosaccharides, cytostatics, component character, treatment by heat, $p H$, UV light, heparin

Growth factors related to several herpesviruses represent a novel class of growth factors produced in some virus infected or transformed cells. Normal. non-transformed cells acquired the transformed phenotype when cultivated in the presence of these factors, whereas the phenotype of transformed cells became changed towards the normal one (Golais et al. 1990; Golais et al. 1992; Dušinská et al. 1994). Purification of these growth factors using discontinuous recycling chromatography (DRC) and gel filtration on the FPLC Superose-12 column revealed, that these factors consist either of two or three components with low molecular weight $(\mathrm{Mr}<1000)$, which differ in their effect on cultured cells in vitro ( $G$ ašperík et al. 1994; Gašperík et al. 1996). Pseudorabies virus (PRV) growth factor (PRGF) was studied more in details and was shown to possess some peculiar properties. Its biological activities could be titrated reaching extremely high titres (up to $10^{18}$ units per $\mathrm{ml}$ ) when resolved into two components (Gašperík et al. 1994). Both transforming and transformed phenotype repressing activity could be unexpectedly elevated by heat, high $\mathrm{pH}$ or UV light, and heparin destroyed the suppressing effect on transformed phenotype without any influence on the transforming activity of PRGF (Golais et al.1996). Glucose and $\mathrm{Ca}^{2+}$ ions were shown to be necessary for PRGF production. The replacement of glucose

\footnotetext{
Address for Correspondence:

Doc. R.NDr. F. Golais. CSc

Department of Microbiology and Virology

Faculty of Natural Sciences. Comenius University

Dubravská cesta 9

$8+245$ Bratislava. Slovak Republic
}

Phone: ++21759413165

Fax: $\quad++217.37+284$ 
in culture medium of PRGF producing cells by other monosaccharides changed both the component composition of PRGF and its effect on cells in vitro ( Kocáková et al. 1996).

Herpes simplex virus type 2 (HSV-2) grow th factor (HSGF-2) has similar properties as compared to PRGF. Both transforming and transformed phenotype repressing activity of HSGF-2 reaching high titres could be neutralized with some monoclonal antibodies (moabs) directed against glycoprotein B ( $\mathrm{gB}$ ) of HSV-2 (Golais et al. 1992), similar to PRGF. which could be neutralized with some moabs against $\mathrm{gB}$ of PRV (Gašperík et al. 1994). As different from PRGF, which consists of two components (Gašperík et al. 1994), HSGF-2 consists of three components (Gašperík et al. 1996). Therefore we decided to study the effect of heat. pH and UV light on HSGF-2 as well as its production in the presence of various ions and monosaccharides in attempts to compare some physicochemical an biological properties of one two-component and one three-component growth factor. Furthermore, the effect of PRGF on transformed Hep- 2 cells was influenced by various cytostatics (Kocák ová et al. 1997). The aim of subsequent experiments was to study the effect of three cytostatics on the production of HSGF-2.

\section{Materials and Methods}

\section{Cell cultures}

Monkey kidney (MK-2) cells were used both for preparation of HSGF-2 as well as for titration of its transforming activity.

Hep-2 tumour cells were used for titration of transformed phenotype repressing activity of HSGF-2. Titration methods as well as definition of one HSGF-2 (PRGF) unit were described previously (Golais et al. 1992).

Both cell lines were cultivated in Eagle's basal medium with $5 \%$ heated bovine serum. glucose $1 \mathrm{~g} / \mathrm{l}$ and glutamine $300 \mathrm{mg} / \mathrm{l}$.

Preparation of $\mathrm{HSGF}-2$

Medium from MK-2 cells infected with US strain of HSV-2 was used as starting material for preparation of HSGF-2 by DRC, which was described previously (Gašperík et al. 1996).

Production of HSGF-2 in the presence of various monosaccharides, ions and cytostatics

Galactose. arabinose. fructose. fucose. xylose and ribose were dissolved in glucose and glutamine free medium to the final concentration $1 \mathrm{~g} / \mathrm{l}$ and added to monolayer of MK-2 cells previously infected with HSV-2 (multiplicity of infection $=1$ ).

Similarly. $\mathrm{Ca}^{2+}$ and $\mathrm{Mg}^{2+}\left(\mathrm{CaCl}_{2}\right.$ and $\left.\mathrm{MgSO}_{+} 0.3 \mathrm{~g} / \mathrm{l}\right)$ in glucose and glutamine containing medium were either removed, or added in two-fold concentration. Furthermore, Carboplatin (Lachema) $200 \mu \mathrm{M}$. Ifosfamid (Asta) $380 \mathrm{M}$ and Methotrexate (Ebewe) $5.5 \mathrm{M}$ in both glucose and glutamine containing medium were used. As control, the medium from infected cells containing glucose, glutamine, $\mathrm{Ca}^{2+}$ and $\mathrm{Mg}^{2+}$ in normal concentrations and without cytostatics was used. To characterize HSGF-2 in all these samples. the media were concentrated 10 -fold by vacuum evaporation and in a volume of $100 \mu$ lapplied directly to a column of FPLC Superose 12 MR (Pharmacia), thus. DRC was omitted in these cases (see Gašperík et al. 1996 for details).

\section{Neutralization of HSGF-2 activity}

Moabs No. 170 and 499 directed against gB of HSV-2 (B ystrická et al. 1991) which were previously shown to neutralize the biological activity of HSGF-2 (Gola is et al. 1992). in the form of the ascitic fluid were diluted 10 -fold in serum free medium. added to $201 \mathrm{HSGF}-2$ samples in an amount of $2 \mu \mathrm{l}$ and incubated at $37^{\circ} \mathrm{C}$ for $90 \mathrm{~min}$. Afterwards the samples were tested in MK-2 and Hep-2 cells grown in wells of flat-bottom microplates (see Golais et al. 1992 for details).

Treatment of HSGF-2 by heat, $\mathrm{pH}$. heparin and UV irradiation

The methods of treatment were the same as reported previously (Golais et al. 1996). The treated HSGF-2 samples were tested and titrated in MK-2 and Hep-2 cells. 


\section{Results}

The production of HSGF-2 in the presence of various monosaccharides, ions and cytostatics

Removal of glucose and glutamine from the cultivating medium resulted in complete inhibition of HSGF-2 production and similar results were obtained following $\mathrm{Ca}^{2+}$ removal. On the other hand, when the medium contained $\mathrm{Ca}^{2+}$ in two-fold concentration, the production of HSGF-2 was enhanced about 10-fold as compared to normal $\mathrm{Ca}^{2+}$ concentration. Absence or abundance of $\mathrm{Mg}^{2+}$ had no effect on HSGF-2 production (Fig.1).

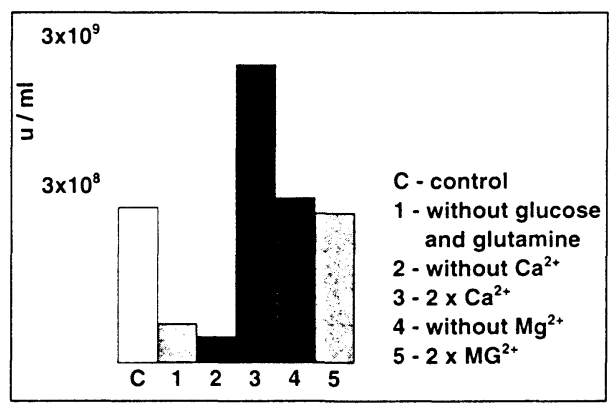

Fig. 1.

The effect of $\mathrm{Ca}^{2+}$ and $\mathrm{Mg}^{2+}$ on production of $\mathrm{HSGF}-2$

When glucose in the medium was replaced by other monosaccharides (glutamine was nod added), following results were obtained ( see Table 1). Two sugars, galactose and fructose produced HSGF-2 transforming MK-2 cells and repressing transformed phenotype in Hep-2 cells, however, such factors were not neutralized with two anti-gB moabs. Three sugars, arabinose, xylose and ribose produced HSGF-2 only with transforming activity, which was neutralized only with moab No. 170. One sugar, fucose did not produce HSGF-2 at all.

HSGF-2 produced in the presence of three cytostatics lost the ability to suppress the transformed phenotype and was not neutralized with moab No. 170 ( Table 2).

Table 1

Production of HSGF - 2 in the presence of various monosaccharides, with titres of transforming ( $\mathrm{MK}-2$ cells) and transformation repressing (Hep-2 cells) activities (both in $\mathrm{U} / \mathrm{ml}$ ).

\begin{tabular}{|l|c|c|c|c|}
\hline Monosaccharide & MK-2 & Hep-2 & Moab 170 & Moab 499 \\
\hline D-glucose & $1.5 \times 10^{7}$ & $4 \times 10^{6}$ & + & + \\
\hline D-galactose & $3 \times 10^{7}$ & $8 \times 10^{6}$ & - & - \\
\hline D-arabinose & $1.5 \times 10^{7}$ & $<10^{1}$ & + & - \\
\hline D-fructose & $6 \times 10^{7}$ & $2 \times 10^{6}$ & - & - \\
\hline D-fucose & $<10^{1}$ & $<10^{1}$ & - & - \\
\hline D-xylose & $2 \times 10^{6}$ & $<10^{1}$ & + & - \\
\hline D-ribose & $8 \times 10^{6}$ & $<10^{1}$ & + & - \\
\hline
\end{tabular}

+ neutralization 
Table 2

Production of HSGF - 2 in the presence of three cytostatics, with titres as given in Table 1

\begin{tabular}{|l|c|c|c|c|}
\hline & MK-2 & Hep-2 & Moab 170 & Moab 499 \\
\hline Control (C) & $1.5 \times 10^{8}$ & $4 \times 10^{7}$ & + & + \\
\hline $\begin{array}{l}\text { Carboplatina } \\
\text { (CAR) }\end{array}$ & $1.2 \times 10^{9}$ & $<10^{1}$ & - & + \\
\hline $\begin{array}{l}\text { Ifosfamid (IFO) } \\
\text { Methotrexate }\end{array}$ & $5 \times 10^{9}$ & $<10^{1}$ & - & + \\
\hline
\end{tabular}

+ neutralization

$\mathrm{C}-$ control $(\mathrm{EBM}+5 \% \mathrm{IBS}+\mathrm{IBS}+$ glucose + glutamine $)$

Gel filtration on the FPLC Superose 12 column showed that HSGF-2 produced in the presence of galactose consist of three components HSGF- $2_{A}$, HSGF- $2_{B}$ and HSGF- ${ }_{C}$, as previously characterized by Gašperík et al. (1996). Transforming activity of A and $\mathrm{C}$ components as well as transformed phenotype repressing activity of $\mathrm{B}$ component were confirmed (see Fig. 2). HSV-2 infected MK-2 cells cultivated in the presence of arabinose yielded HSGF-2 only with one component which possessed only transforming activity (Fig. 3). Similarly, a one-component HSGF-2 was obtained in the presence of methotrexate (Fig. 4).

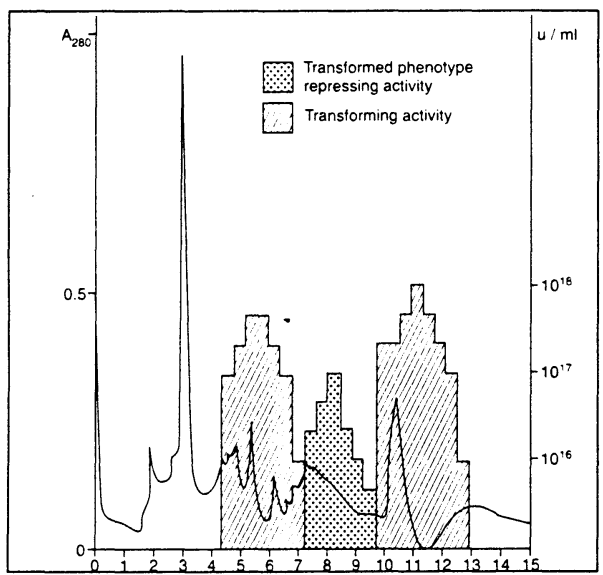

Fig. 2.

The effect of galactose on the synthesis and the activity of HSGF-2

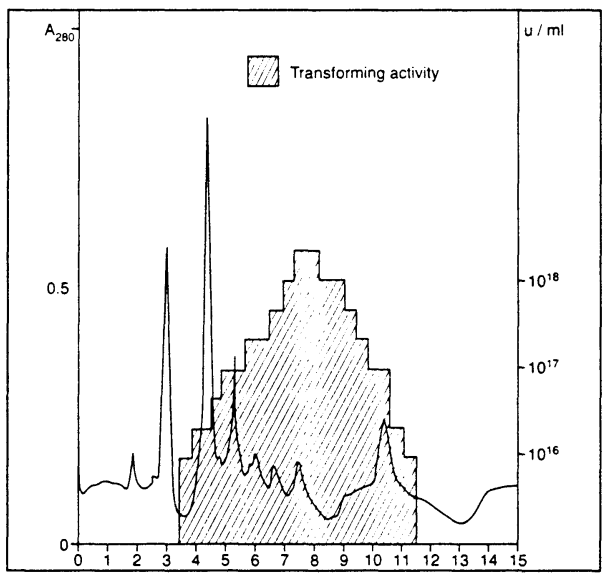

Fig. 3.

The effect of arabinose on the synthesis and the activity of HSGF-3

Some physico-chemical properties of HSGF-2

The effect of temperature and UV irradiation

Both non-resolved HSGF-2 and its separated three components were exposed to the temperatures of $30^{\circ} \mathrm{C}, 50^{\circ} \mathrm{C}$ and $70^{\circ} \mathrm{C}$ and heated for $30 \mathrm{~min}$. These temperatures elevated 
the transforming activity of non-resolved HSGF- 2 and its A and C components (Fig. 5 shows only isolated $\mathrm{A}$ and $\mathrm{C}$ components), whereas the transformation repressing activity of nonresolved HSGF- 2 and HSGF- ${ }_{B}$ remained unchanged. We failed to ascertain any kinetics in elevation of the transforming activity. The enhanced values shown in Fig. 5 representing those obtained after $30 \mathrm{~min}$ heating appeared as soon as after $2 \mathrm{~min}$ and prolonged heating

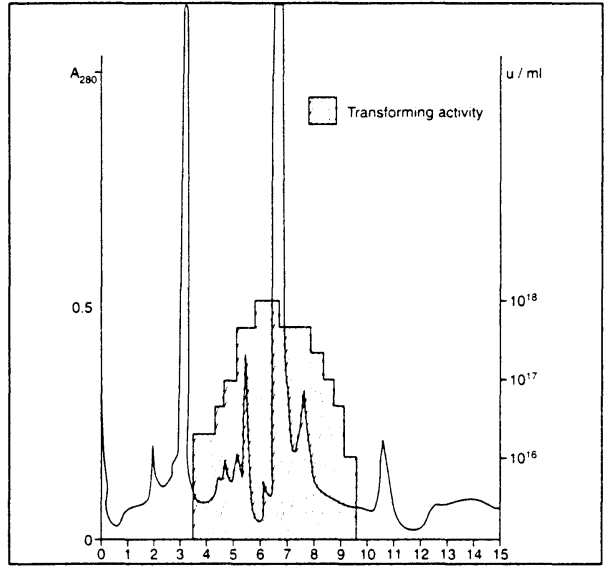

Fig. 4.

The effect of methotrexate on the synthesis and the activity of HSGF-2

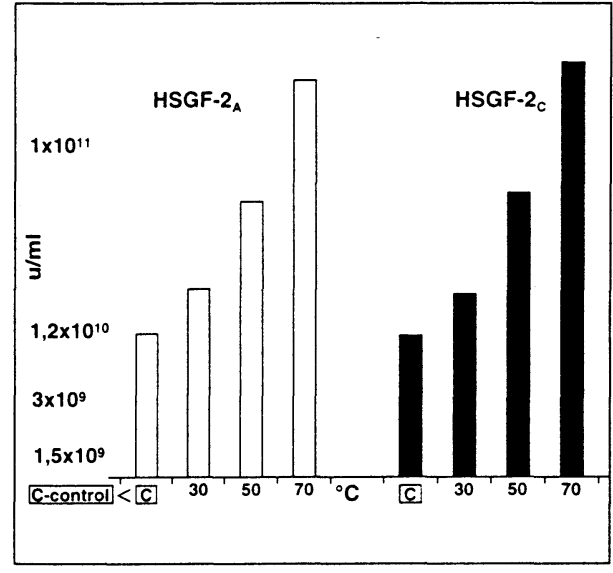

Fig. 5 .

The effect of temperature on two components of HSGF-2 following 30 minutes heating

did not lead to further titres elevation. Similar enhancing effect on transforming activity was observed following UV irradiation (Fig. 6). The transformed phenotype repressing activity of non-resolved HSGF-2 or its B component was not impaired by UV light.

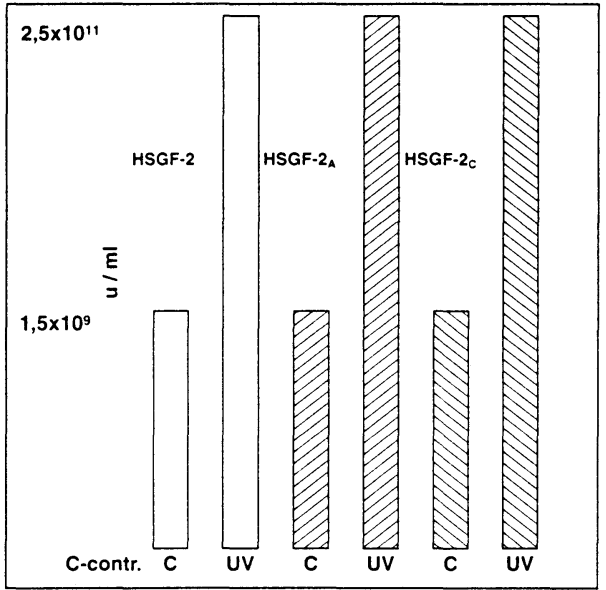

Fig. 6.

The effect of UV irradiation on HSGF-2 and its two components following $3 \mathrm{~min}$. exposure

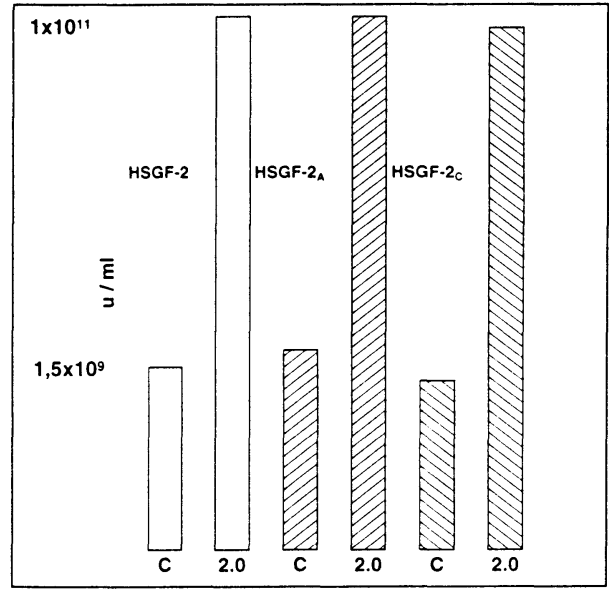

Fig. 7.

The effect of $\mathrm{pH} 2,0$ on transforming activity of HSGF-2 and its components (C-control at pH 7,2)

The effect of various $\mathrm{pH}$ values on HSGF-2 activity

The transforming activity of HSGF- 2 and its $\mathrm{A}$ and $\mathrm{C}$ components remained unchanged at $\mathrm{pH}$ 7.5-10. A slight increase was demonstrated at $\mathrm{pH} 4.5$ (data not shown) and reached 
maximum at $\mathrm{pH} 2$ (Fig. 7). Low pH had no effect on transformation repressing activity of non-resolved $\mathrm{HSGF}-2$ or $\mathrm{HSGF}-2_{\mathrm{B}}$.

\section{Heparin treatment}

Heparin treatment [3\% W/V in bidistilled water - for details see Golais et al. (1996)] had not effect on transforming activity of non-resolved HSGF-2 or its A and C components. However. the transformation repressing activity was removed when either non-resolved HSGF-2 or B component were treated.

\section{Discussion}

PRGF was shown to consist of two components. PRGF ${ }_{A}$ and PRGF $_{B}$ alone possess only transforming activity. For appearance of transformed phenotype repressing activity either non-resolved PRGF. or both components acting simultaneously are needed ( $\mathrm{G}$ ašperík et al. 1994). On the other hand, HSGF-2 consists of three components. HSGF-2 and HSGF$2_{C}$ have only transforming activity and are not able to repress the transformed phenotype. This activity is pertinent only to HSGF- $2_{\mathrm{B}}$, however, this component is devoid of transforming activity ( $\mathrm{Gašperík}$ et al. 1996). The differences in component composition might be a reason for some physico-chemical and biological differences between PRGF and HSGF-2 presented in this paper.

Both PRGF and HSGF-2 require glucose and $\mathrm{Ca}^{2+}$ for their successful synthesis. Monosaccharides replacing glucose may influence the properties of PRGF and HSGF-2 in different ways. For example, in the presence of fructose or fucose only one-component PRGF devoid of transformation repressing activity was produced, whereas fructose gave rise to HSGF-2 with both activities, and no HSGF-2 was produced in the presence of fucose (for other differences compare Table 1 and Kocáková et al. 1996).

HSGF-2 produced in the presence of three cytostatics lost the ability to change the transformed phenotype, and as shown with methotrexate, it contained only one component (Fig. 4). Such effect was also brought about by some monosaccharides. however in this case the neutralization with the moab No. 499 was lost (Table 1), whereas HSGF-2 produced in the presence of cytostatics could not be neutralized with moab No.170 (Table 2).

More remarkable differences were found studying the effect of heat, $\mathrm{pH}$, UV light and heparin on HSGF- 2 activities and comparing the results with those obtained with PRGF. The titres of both transforming and transformed phenotype repressing activity of PRGF were repeatedly elevated to constant values at each chosen temperature within a constant time, and similar enhancement was observed following UV irradiation (Golais et al. 1996). As different from PRGF, as shown in this paper, the transforming activity of both non-resolved HSGF-2 and its A and C components was similarly enhanced at three chosen temperatures, however this enhancement appeared much more quickly, within minutes.

Furthermore, the ability of non-resolved HSGF-2 or HSGF- ${ }_{\mathrm{B}}$ to repress the transformed phenotype was not influenced either by heat, or by UV light.

The activity of PRGF and its two components remained unchanged at pH $3.0-7.6$ and an increase in both activities was demonstrated at $\mathrm{pH} 8-9.5$ (Golais et al. 1996). An opposite effect was observed when HSGF-2 was exposed to various pH. Alkali had no effect on its activities, however the transforming activity was elevated at $\mathrm{pH} 2-4.5$. The ability to repress the transformed phenotype, as different from PRGF (Golais et al. 1996) was not affected by $\mathrm{pH}$. 
The removal of transformed phenotype repressing activity by heparin previously shown with PRGF (Golais et al. 1996) was also demonstrated with HSGF-2. It supports the view that this activity might be located in a structure domain with a binding site for heparin (Sawitzky et al. 1990).

All results obtained both with PRGF and HSGF-2 indicate, that a peculiar structure of these novel growth factors might be expected and some appropriate methods must be chosen in attempts to define it.

\section{Stúdia niektorých biologických a fyzikálno-chemických vlastností rastového faktora vírusu herpes simplex typu 2 (HSGF-2)}

Vírus herpes simplex typu 2 (HSV-2) produkuje rastový faktor (HSGF-2), ktorý pozostáva z troch komponentov. Komponenty HSGF-2 ${ }_{\mathrm{A}}$ a HSGF-2 $2_{\mathrm{C}}$ majú schopnost transformovat bunky v kultúrach in vitro, kým komponent HSGF-2 ${ }_{B}$ mení transformovaný fenotyp buniek na fenotyp normálny. Na produkciu funkčného HSGF-2 je potrebná glukóza a ióny $\mathrm{Ca}^{2+}$. Zámena glukózy za iné monosacharidy, alebo prítomnost troch druhov cytostatík v médiách, v ktorých rastú bunky MK-2 produkujúce HSGF-2 ovplyvňovala jednak biologickú aktivitu HSGF-2, jednak jeho komponentové zloženie. Zahrievanie, nízke $\mathrm{pH}$ alebo UV žiarenie zvyšovali transformačnú schopnosṫ HSGF-2, nie však jeho schopnost potláčat transformovaný fenotyp. Heparín rušil schopnost potláčania transformovaného fenotypu, nemal ale vplyv na transformačnú aktivitu HSGF-2. Všetky uvádzané výsledky sú porovnávané s podobnými alebo odlišnými výsledkami, ktoré boli dosiahnuté s rastovým faktorom vírusu pseudorabies (PRGF).

\section{References}

BYSTRICKÁ. M.. VANČÍKOVÁ, M., KASALOVÁ, M.. RAJČÁNI. J., KOŠT̃ÁL. M.. MURÁNYIOVÁ, M., POLÁKOVÁ. K. 1991: Typecommon and typespecific monoclonal antibodies to herpes simplex virus type 1 and type 2. Acta virol. 35: 152-164

DUŠINSKÁ, M.. LEŠKO. J.. GOLAIS. F.. SLAMEÑOVÁ. D. 1994: Morphological transformation of Syrian hamster embryo cells by pseudorabies virus related grow th factor. Cancer Lett. 79: 125-130

GAŠPERÍK. J.. LESKKO. J.. CSABAYOVA.. M.. GOLAIS. F. 1994: Pseudorabies virus growth factor ( PRGF) can be resolved into two active components. Acta virol. 38: 117-120

GAŠPERÍK. J.. LEŠKO. J.. GOLAIS. F. 1996: Growth factor encoded by various herpesviruses can be resolved in two or three components. Biol.Zentbl. 115: 71-77

GOLAIS. F.. LESKKO. J.. HILLEROVÁ. A.. KOLCUNOVȦ. A.. SABÓ. A. 1990: Putative virus-encoded growth factor in a crude extract of pseudorabies virus infected and transformed human cells. Biol.Zentbl. 109: $481-487$

GOLAIS. F.. CSABAYOVÁ. M.. LEŠKO. J.. BYSTRICKÁ. M.. SABÓ. A. 1992: Herpes simplex virus type 2 and pseudorabies virus associated grow th factors and their role in the latency in vitro. Acta virol. 36: 505-515

GOLAIS. F.. GAŠPERÍK. J.. LEŠKO. J.. DUŚINSKÁ. M. 1996: The effect of heat. pH urea and ultraviolet light on pseudorabies virus growth factor ( PRGF) activity. Biol. Zentbl. 115: 357-366

KOCÁKOVÁ. P.. VANČOVÁ. I.. GAŚPERÍK. J.. LEŚKO. J.. GOLAIS. F. 1996: Production of pseudorabies virus grow th factor ( PRGF) in the presence of various monosaccharides and cations. Biol. Zentbl. 115: 353-356

KOCÁKOVÁ. P.. LEŚKO. J.. HORÁKOVÁ. K.. GOLAIS. F. 1997: A combined effect of pseudorabies virus grow th factor ( PRGF) and various cytostatics on tumour (Hep-2) cells in vitro. Acta vet. Brno 66: 159-169

SAWITZKY. D.. HAMPL. H.. HABER.MEHL. K. O. 1990: Comparison of heparin sensitive attachment of pseudorabies virus (PRV) and herpes simplex virus type 1 and identification of heparin-binding PRV glycoproteins. J. Gen. Virol. 71: 1221-1225 